\title{
Analysing Motivations for Sports Consumption of Students at School of Physical Education and Sports
}

\section{Murat AYGÜN ${ }^{1}$ Elif Kübra Demir² (D)}

'Ardahan University, School of Physical Education and Sports; Sports Management Sciences, Turkey. Email:avgunmurato6@gmail.com

${ }^{2}$ Ege University, Faculty of Education; Measurement and Evaluation in Education, Turkey. Email:elif.kubra.demir@ege.edu.tr

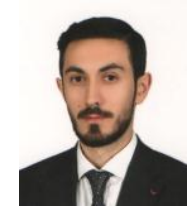

\begin{abstract}
In this study, the objective is to analyse the motivation for sports consumption of university students. The study group consists of 178 students in School of Physical Education and Sports. As data collection tool in the research, Personal Information Form and Motivation Scale for Sport Consumption" developed by Trail and James (2001) and adapted into Turkish by Tok (2004) have been used. Independent samples t-test and variance analysis are used for independent groups. There are significant differences in favour of female in the sub-dimension of family and in favour of students studying at sports management in the sub-dimension of knowledge and skills on the scores of motivation scale for sport consumption. While the averages are high at people living in the cities in the sub-dimension of social, the averages are low at people living in towns. According to findings of the research, it has been thought that consumption requirement arising with motives and motivation phenomenon plays an active role in motivation behaviour of the sports in line with the requirements of the individuals such as socialization, self-proofing and selfacceptance.
\end{abstract}

Keywords: Physical education, Consumption, Sports consumption, Motivation.

Citation | Murat AYGÜN; Elif Kübra Demir (2020). Analysing Motivations for Sports Consumption of Students at School of Physical Education and Sports. Asian Journal of Education and Training, 6(2): 314-319.

History:

Received: 17 February 2020

Revised: 20 March 2020

Accepted: 29 April 2020

Published: 1 June 2020

Licensed: This work is licensed under a Creative Commons

Attribution 3.0 License (oc)

Publisher: Asian Online Journal Publishing Group
Acknowledgement: Both authors contributed to the conception and design of the study.

Funding: This study received no specific financial support.

Competing Interests: The authors declare that they have no conflict of interests.

Transparency: The authors confirm that the manuscript is an honest, accurate, and transparent account of the study was reported; that no vital features of the study have been omitted; and that any discrepancies from the study as planned have been explained.

Ethical: This study follows all ethical practices during writing.

\section{Contents}

1. Introduction 


\section{Contribution of this paper to the literature}

The desires and motives in the concept of motivation play an active role in determining the consumption need in the phenomenon of sports. Thanks to the importance and scope of sports marketing with the phenomenon of consumption; it will contribute to the sports science by providing resources for studies in the fields of motivation, marketing and sports consumption.

\section{Introduction}

With the emergence of the sports phenomenon, large audience has also increased with the development of sports. This increased interest has played an active role in the motivation assessment of sports need by causing a growth in the consumption factor in sports marketing. Thanks to today's technological advancements, the consumption factor (audience, sports fan, association, club, foundation... etc.) in sports has been improving and showing its effect at a universal level. Motivation is an important factor in this universality.

The word "motivation", which is expressed as actions taken to affect individuals, has come from the root of "mot" in Latin and is defined as the concept of motivation (Hanks, 1999; Tevruz, 2002). While motivation is directed towards the expectations of individuals, the sense of curiosity, continuity, learning, performance, sociological and psychological factors in the realization of the consumption decision (Elmas \& Balc1, 2019; Middleton \& Toluk, 1999; Vallerand et al., 1992) show specificity in the concept of sports consumption on personal needs.

While providing the needs, tension, motives, research behaviour, satisfaction of needs and decreasing the sense of tension are rendered as basic motivation process, psychological skills are very important in providing the motivation factor (Erhan, Bedir, Güler, \& Ağduman, 2015; Keser, 2006). Some similar situations (self-confidence and performance etc.) are very important in determining the behaviour action (Cohen, 2016). Additionally, cultural, social and family factors that can be considered in consumption will benefit the socialization process of the individual (Aygün \& Oztaşyonar, 2019). The motivations that emerge in the individual are very important for increasing the attractiveness and interest that occupy psychological needs.

The condition of active or passive participation in any sport branch is very substantial in terms of the economic value of the sports industry. Searching people's participation in sports and learning the results of this situation will benefit the learning of the emerging economic dimension (Erkan \& Uslu, 2019). Physical participation and passive sports consumption practices are different from each other in sports participation (Kim \& Mao, 2019). It has been stated that the main element of the sports consumption of the studies on participation in sports are motives (Simşek, 2012). Continuity of the researches on consumption, which is one of the main economic activities (Xianliang \& Hongying, 2012) and how it affects today's sports consumption behaviour with developing technology have importance (Ha, Kang, \& Kim, 2017). While sports activities took place in local criteria in the past, it helps the sport reach to a wide audience with the development of technology. Thanks to the increasing interest in sports, specialization (professionalization) in sports has started to advance. This situation displays us that there are such dimensions like production and marketing as well as being healthy. Furthermore, the products that sports clubs have created for branding have resulted in large income sources and the emergence of sports marketing activities (Erdoğ, 2012; Kurtipek, Güngör, Esentürk, Ilhan, \& Yenel, 2020; Murathan \& Murathan, 2019). The increase in new models with the development of technology has caused the needs of the consumer to change and increased the importance of the sports market (Biricik, 2019). Denoted in the study of Xianliang and Hongying (2012) "Baidu: the costs that arise after people participate in the activities" are expressed as sports consumption. Regarding the football branch, which has a high market volume in sports consumption in our country, the effectiveness of sports experts and marketers will contribute to increasing audience participation (Gençer, Kiremitçi, Aycan, Demiray, \& Unutmaz, 2012). In this event, the effectiveness of sports consumption will become more prominent and will cause the growth of the market and sports within the scope of consumption phenomenon.

Factors affecting the defined sports consumption motivation has been expressed as the basic needs of sports consumers by putting forward as 14 basic themes. It is possible to mention 3 different participations (live participation, mediated sports consumption and common motivational behaviour) that form the motivational behaviour. In "live participation motivational behaviour", there are 3 themes that affect consumption motivation such as witnessing history, identity creation and reality. In "mediated sports consumption motivational behaviour", there are 8 themes such as multiple game access, economic thought in many aspects, protection from emotional risk, suitability, programming, sociability etc. and lastly, there are 3 themes in the "common motivational behaviour" with consumption motivation including admiration, socialization and entertainment (Kim \& Mao, 2019).

Although it is stated that the person is identified with the consumption behaviour in sports with the feature of the sports branch, sports consumption motivation is both the tendency and activation of the sports consumption phenomenon (Ceylan, Altıparmak, \& Akçakoyun, 2016; Xianliang \& Hongying, 2012). Sports consumption motivations and their explanations described by Kim and Mao (2019) are defined as follows:

- Live Participation Motivational Behaviour: Motivation to witness the history of the games, to develop their own identity, to have a direct experience.

- Mediated Sports Consumption Motivational Behaviour: Motivation of being able to do several sports at the same time, being engaged with other things while doing sports, doing low cost sports activities, protecting yourself from emotional exhaustion of other people, following their autonomy and privacy, getting information about sports through explanations, interacting with other people better via sports, having your favourite sports games.

- Common Motivational Behaviour: Motivation to express their admiration about teams or players, to develop new relationships with others along with sports consumption, and to be satisfied and happy through sports consumption (Kim \& Mao, 2019).

In line with this study; the importance of sports for the public and the individuals' interest in sports increase with the developing technology. 
The media element that we encounter as an important factor today reveals the strength of economically sports marketing and the determining the consumption phenomenon of people. It has been thought that the most important reasons for the emergence of the consumption factor are wishes, desires and motivation. In this study, it is aimed at analysing the sports consumption motivations of individuals as a result of the mathematical values obtained in line with some demographic variables (gender, department and place of residence) that form the personal information form of the research.

\section{Method}

This part of this study includes information about the model of the research, research population and sample, data collection tools and statistical techniques used in the analysis of the data.

\subsection{Research Model}

In this study, the survey model, one of the quantitative research models, has been used. In order to determine the specific characteristics of a group (age, gender, ethnicity...), studies whose objective is to collect data about the characteristics of events and situations are called survey models (Büyüköztürk, Çakmak, Akgün, Karadeniz, \& Demirel, 2013; Fraenkel \& Wallen, 2006).

\subsection{Study Group}

The study group consists of 178 students (88 females, 90 males), aged between 18-26, who studies at Ardahan University, School of Physical Education and Sports.

\subsection{Data Collection Tools}

In the study, Personal Information Form containing demographic features prepared by the researcher and Motivation Scale for Sport Consumption have been used to analyse students' motivations for sports consumption.

- Personal Information Form (PIF): In the research, information about independent variables and questions considering demographic variables such as gender, age, department, class and place of residence formed by the researcher.

- Motivation Scale for Sports Consumption: To measure students' sports consumption motivations; "Motivation Scale for Sports Consumption", which is developed by Trail and James (2001) and adapted into Turkish by Tok (2004) has been used. This scale includes 27 items and 9 sub-dimensions (Success, knowledge, aesthetics, stress, escape, family, physical attraction, physical skill, social). The scale is 7-point Likert type and the items as such: 1-Strongly disagree, 2-Partially disagree, 3-Disagree, 4-Neutral, 5-Agree, 6-Partially agree, 7Strongly agree. The reliability coefficient of the scale has been found to be between .63 and .89 in terms of subdimensions (Tok, 2004).

\subsection{Statistical Interpretation of Data}

The scores obtained from the sub-dimensions of the motivation scale for sports consumption have been compared in terms of gender, age, department, class and location variable. Normal distribution, homogeneity and linearity assumptions of variances have been tested and assumptions have been provided. Thusly, the data has been analysed by variance analysis.

\section{Findings}

The demographic variables belonging to the students constituting the study group of the research are presented in the Figure 1 the scores obtained from the motivation scale for sports consumption are presented in the Table 1, Table 2 and Table 3 according to the sub-dimensions.

\section{Demographic Features}

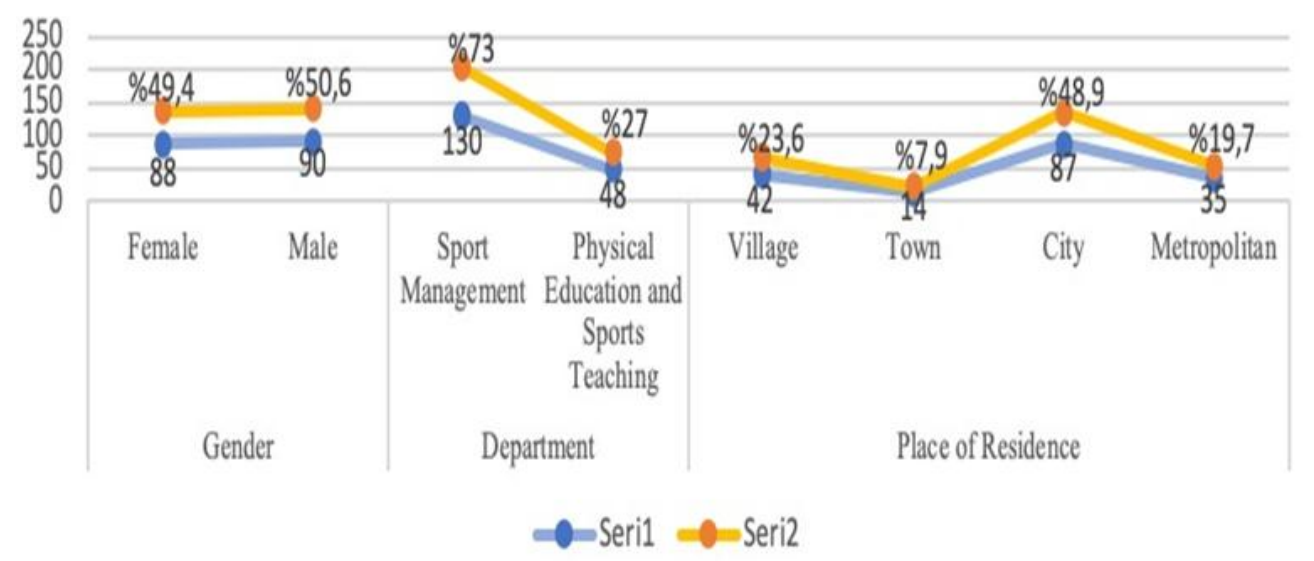

Figure-1. Demographic features of the students.

In Figure 1, according to gender variable; 90 are male students (50.6\%) and 88 are female students (49.4\%) of the participants. According to the department variable, 130 students take education in the sports management department $(73.0 \%)$, and 48 of them study in the physical education and sports teaching department $(27.0 \%)$. According to the place of residence variable; 42 students live in the village (23.6\%), 14 students live in the town $(7.9 \%)$ and 87 students live in the city $(48.9 \%)$ and 35 students live in the metropolitan area (19.7\%). 
Table-1. The findings of the comparison about the scores obtained from motivation scale for sports consumption regarding gender variable.

\begin{tabular}{|c|c|c|c|c|c|c|}
\hline SMSSC & Gender & $\mathbf{N}$ & $\bar{X}$ & $\mathbf{S}$ & $\mathbf{t}$ & $\mathbf{P}$ \\
\hline \multirow{2}{*}{ Success } & Male & 90 & 17,433 & 5,266 & \multirow{2}{*}{.273} & \multirow{2}{*}{.807} \\
\hline & Female & 88 & 17,227 & 4,805 & & \\
\hline \multirow{2}{*}{ Knowledge } & Male & 90 & 15,311 & 5,422 & \multirow{2}{*}{.588} & \multirow{2}{*}{.199} \\
\hline & Female & 88 & 14,897 & 4,707 & & \\
\hline \multirow{2}{*}{ Aesthetics } & Male & 90 & 17,311 & 4,691 & \multirow{2}{*}{.466} & \multirow{2}{*}{.638} \\
\hline & Female & 88 & 16,806 & 4,515 & & \\
\hline \multirow{2}{*}{ Stress } & Male & 90 & 15,644 & 5,066 & \multirow{2}{*}{.741} & \multirow{2}{*}{.415} \\
\hline & Female & 88 & 15,886 & 4,659 & & \\
\hline \multirow{2}{*}{ Escape } & Male & 90 & 14,333 & 4,873 & \multirow{2}{*}{.855} & \multirow{2}{*}{.239} \\
\hline & Female & 88 & 14,204 & 4,503 & & \\
\hline \multirow{2}{*}{ Family } & Male & 90 & 13,200 & 6,091 & \multirow{2}{*}{.544} & \multirow{2}{*}{$.034 *$} \\
\hline & Female & 88 & 13,715 & 5,174 & & \\
\hline \multirow{2}{*}{ Attraction } & Male & 90 & 12,011 & 4,851 & \multirow{2}{*}{.900} & \multirow{2}{*}{.961} \\
\hline & Female & 88 & 12,102 & 4,849 & & \\
\hline \multirow{2}{*}{ Skill } & Male & 90 & 17,300 & 4,453 & \multirow{2}{*}{.617} & \multirow{2}{*}{.975} \\
\hline & Female & 88 & 16,965 & 4,431 & & \\
\hline \multirow{2}{*}{ Social } & Male & 90 & 16,177 & 4,763 & \multirow{2}{*}{.014} & \multirow{2}{*}{.612} \\
\hline & Female & 88 & 14,363 & 5,033 & & \\
\hline
\end{tabular}

Note: *p< $\mathbf{0 . 0 5}$ SMSSC: Sub-dimensions of Motivation Scale for Sports Consumption.

In Table 1, when the findings about the students' scores from the scale are analysed according to the gender variable, it is observed that the average score of female students is higher than male students in the subdimensions of "stress and attraction". On the other hand, male students have higher averages than female students in terms of "success, knowledge, aesthetics, escape, skill, and social" sub-dimensions ( $>$.05). In the "family" sub-dimension, females ( $\overline{\mathrm{X}}: 13.72$, S:6.09) have higher averages and there is a significant difference $(\mathrm{p}=.034)$ considering male students $(\mathrm{p}<.05)$.

Table-2. The findings of the comparison about the scores obtained from motivation scale for sports consumption regarding department variable.

\begin{tabular}{|c|c|c|c|c|c|c|}
\hline$\overline{\text { SMSSC }}$ & Department & $\mathbf{N}$ & $\bar{X}$ & $\mathbf{S}$ & $\mathbf{t}$ & p \\
\hline \multirow[t]{2}{*}{ Success } & Sports Management & 130 & 17,500 & 4,866 & \multirow{2}{*}{.735} & \multirow{2}{*}{.164} \\
\hline & Physical Education and Sports Teaching & 48 & 16,875 & 5,479 & & \\
\hline \multirow[t]{2}{*}{ Knowledge } & Sports Management & 130 & 15,223 & 4,749 & \multirow{2}{*}{.503} & \multirow{2}{*}{$.025^{*}$} \\
\hline & Physical Education and Sports Teaching & 48 & 14,791 & 5,899 & & \\
\hline \multirow[t]{2}{*}{ Aesthetics } & Sports Management & 130 & 17,100 & 4,608 & \multirow{2}{*}{.182} & \multirow{2}{*}{.622} \\
\hline & Physical Education and Sports Teaching & 48 & 16,958 & 4,621 & & \\
\hline \multirow[t]{2}{*}{ Stress } & Sports Management & 130 & 15,738 & 4,837 & \multirow{2}{*}{.115} & \multirow{2}{*}{.896} \\
\hline & Physical Education and Sports Teaching & 48 & 15,833 & 4,960 & & \\
\hline \multirow[t]{2}{*}{ Escape } & Sports Management & 130 & 14,092 & 4,465 & \multirow{2}{*}{.831} & \multirow{2}{*}{.108} \\
\hline & Physical Education and Sports Teaching & 48 & 14,750 & 5,241 & & \\
\hline \multirow[t]{2}{*}{ Family } & Sports Management & 130 & 13,623 & 5,531 & \multirow{2}{*}{.652} & \multirow{2}{*}{.472} \\
\hline & Physical Education and Sports Teaching & 48 & 13,000 & 5,985 & & \\
\hline \multirow[t]{2}{*}{ Attraction } & Sports Management & 130 & 11,861 & 4,784 & \multirow{2}{*}{.883} & \multirow{2}{*}{.977} \\
\hline & Physical Education and Sports Teaching & 48 & 12,583 & 4,988 & & \\
\hline \multirow[t]{2}{*}{ Skill } & Sports Management & 130 & 17,469 & 4,120 & \multirow{2}{*}{1.664} & \multirow{2}{*}{$.026 *$} \\
\hline & Physical Education and Sports Teaching & 48 & 16,229 & 5,124 & & \\
\hline \multirow[t]{2}{*}{ Social } & Sports Management & 130 & 15,353 & 5,091 & \multirow{2}{*}{.322} & \multirow{2}{*}{.317} \\
\hline & Physical Education and Sports Teaching & 48 & 15,083 & 4,666 & & \\
\hline
\end{tabular}

Note: *p<0.05 SMSSC: $\mathrm{S}$ Sub-dimensions of Motivation Scale for Sports Consumption.

In Table 2, when the findings related to the students' scores from the scale are analysed according to the department variable, it is found that the scores of sports management department are higher averages than the physical education and sports teaching department in the sub-dimensions of "success, aesthetics, family and social". There is also a higher average in physical education and sports teaching department than sports management in the sub-dimensions of "stress and attraction" but there is no significant difference between them (p> .05). In the sub-dimension of "knowledge" $\overline{\mathrm{X}}: 15.22$, S: 4.75; "Skill" $\overline{\mathrm{X}}: 17.47$, students seem to have a significantly higher average at the sports management department $(\mathrm{p}<.05)$.

Table-3. The findings of the comparison about the scores obtained from motivation scale for sports consumption regarding place of residence variable.

\begin{tabular}{c|c|c|c|c|c|c}
\hline SMSSC & Residence & $\mathbf{N}$ & $\overline{\boldsymbol{X}}$ & $\mathbf{S}$ & $\mathbf{F}$ & $\mathbf{p}$ \\
\hline \multirow{3}{*}{ Social } & Village & 42 & 15,071 & 4,122 & & \\
\cline { 2 - 7 } & Town & 14 & 12,571 & 5,879 & 2.694 & \\
\cline { 2 - 7 } & City & 87 & 16,149 & 4,893 & & \\
\cline { 2 - 7 } & Metropolis & 35 & 14,457 & 5,343 & & \\
\hline
\end{tabular}

Note: *p<0.05 SMSSC: S Sub-dimensions of Motivation Scale for Sports Consumption.

In Table 3, when the variance analysis findings are analysed according to place of residence variable, there is no substantial difference in the sub-dimensions of "success, knowledge, aesthetics, stress, escape, family, attraction and skill" ( $\mathrm{p}>$.05). In the sub-dimension of "social" $(\mathrm{F}=2.694 \mathrm{p}=.048)$ while individuals living in the city have highest average; the individuals living in the town have the lowest average $(p<.05)$. 


\section{Discussion and Results}

This study, which has been done so as to determine the motivations of physical education and sports school students for sports consumption, has been reviewed in line with various demographic variables, and the findings have been presented by comparing with the previous studies in the literature.

According to the gender variable, among the demographic variables, $50.6 \%$ are male and $49.4 \%$ are female participants. According to the department variable, $73.0 \%$ of research group study in the department of sports management, $27.0 \%$ of them study in the department of physical education and sports teaching. Considering the place of residence variable, $23.6 \%$ of participants live in the village, $7.9 \%$ of them live in the town, $48.9 \%$ of them live in the city and $19.7 \%$ of them live in the metropolitan area.

In Table 1, there is a significant difference in favour of female students in the sub-dimension of "Family" regarding gender variable $(\mathrm{p}<.05)$. There are no significant differences in terms of other sub-dimensions according to gender variable $\mathrm{p}>.05$ ). As a result of this finding; the family and cultural structure is considered to be a major factor in the phenomenon of sports consumption. Although men play an active role in the consumption of sports in comparison to women in the social structure, women are active in the family subdimension. Women are affected by family members in sports consumption, acting together with family members and performing sports consumption by displaying behaviour in this direction.

Effect of sports fans' motivation factors on behavioural loyalty by Giray and Girişken (2015): on the Fenerbahce Sports Club as a case study, the reasons for the identification of individuals participating in the research with their clubs can be expressed as the artistic structure of the sport, the aesthetics and the feeling of excitement while watching the sports club as well as spending time with family members. In the study of the relationship between the football fans' motivations for sports consumption, their perceptions of risk and future participation intentions by Cinarlı (2019) there are significant differences in favour of women in the subdimension of knowledge acquisition. However, there is no significant difference for other sub-dimensions. The reason for this is stated as the need for women to obtain information more than men. The studies of Cinarl (2019) and Karatoprak (2019) are partially similar to our study.

In the study titled "analysing football fans' motivations towards sport consumption: Beşiktaş Jk-Kardemir Karabukspor as a case" by Cokportal (2015) although there are meaningful results in favour of men in the subdimension of aesthetic and physical skills of Kandemir Karabükspor fans; there is no significant difference on the fans of Beşiktaş JK regarding gender variable. While the meaningful result is expressed as such: men are much more interested in football than women. While the significant situation is linked to the physical skills and aesthetics of men in football; the insignificant condition is associated with the high motivation perceptions of female fans. The work of Simşek (2011) on extreme sports consumption motives does not show parallelism with our study.

When the studies on motivation in literature is examined; in the study of comparing the motivation levels of sport-specific success in terms of genders in professional basketball players by Aktas, Çobanoğlu, Yazıcılar, and Er (2006) it has been claimed that expectations, cultural and social characteristics are the factors that men have more power than women athletes, and the motivation of men to approach success is lower than women in terms of studies regarding gender variable. In Ozgün, Yaşartürk, Ayhan, and Bozkuş (2017)'s study on the relationship between the handball players' sport-specific success motivation and happiness levels, there is no significant difference in the sub-dimension of sport-specific success motivation. In the study of sustainable sports consumer behaviour conducted by Yüce (2019) it has been observed that sports consumption is in favour of men in line with the perception of sustainable development, perception of sustainability in sports, environmental sensitivity in sports, consumption of sports products and purchase intent according to gender variable. In the study on the physical ethics and professional motivation of physical education and sports teachers by Karayol and Eroğlu (2020) there is no significant difference from professional motivation behaviours according to gender variable. In the study of Elmas (2018) it is stated that sports consumption is higher among men. This assumption is also related to the number of male and female athletes specified by the Ministry of Youth and Sports. In the study conducted by Elmas and Balcı (2019) about the sports consumption of university students, it is understood that there is a significant difference in favour of men in line with the gender variable. In the study by Cini (2018) titled as "relationship between online sports consumption motives and loyalty points of professional football team supporters", it has been stated that the meaningful difference in the sub-dimensions of entertainment and support in favour of women is in the desire to enjoy the storyline process rather than the technical part of the football branch.

In Table 2; there is a significant difference in favour of students of sports management in the sub-dimension of "knowledge and skill" according to department variable ( $p<.05)$. Regarding department, it is considered as the reason for this result to explain the necessity of the sport in terms of organizational structure, sports marketing, sports management or use of sports in the sports management departments.

In Table 3, individuals living in the city have higher average in the "social" sub-dimension than other variables according to place of residence variable $(\mathrm{p}<.05)$. In line with the social structure, it is understood that individuals living in the city interact with the environment as a result of motivation, emotions and requests from the moment they begin their education. With this in mind, it is thought that sports activities in cities are more than small settlements; individuals constantly interact with the environment; and the effectiveness of concepts such as advertising and marketing cause sports consumption to be effective in cities on a social scale.

As a result of the research, the concept of sports consumption is regarded as a financially important sector worldwide. The main source of this is thought to be the socialization needs of people by considering themselves as a member of the society. In line with this thought; social norms such as proving themselves, sense of belonging, being a part of a group as well as desires, motivation, consumption, consciousness and subconscious thoughts are determinative reasons for the realization of consumption in sports. It is thought that realization of the consumption phenomenon in sports will have an effect on the individual status gain together with the social phenomenon, apart from the expansion of the sports market volume and the person's wishes. 


\section{References}

Aktas, Z., Çobanoğlu, G., Yazıcılar, İ., \& Er, N. (2006). The comparison of sports related success motıvatıon level among professional basketball players in terms of gender. SPORMETRE the Journal of Physical Education and Sports Sciences, 4(2), 55-59.

Aygün, M., \& Oztaşyonar, Y. (2019). Analysing sports trait self-confidence features of ice hockey players. SPORMETRE The Journal of Physical Education and Sports Sciences, $17(3)$, 202-212.

Biricik, Y. S. (2019). Customer loyalty in the sports industry: A research on sports shoes/trainers market. Journal of Sport and Performance Researches, $10(3), 312-324$.

Büyüköztürk, Ş., Çakmak, E. K., Akgün, Ö. E., Karadeniz, Ş., \& Demirel, F. (2013). Sceintific research models (pp. 15-17). Ankara: Pegem Academy.

Ceylan, M., Altıparmak, E., \& Akçakoyun, F. (2016). The analysis of the relationship between personality traits of extreme athletes and sports consumption motives. Journal of Human Sciences, 13(1), 1745-1754.Available at: https://doi.org/10.14687/ijhs.v13i1.3416.

Cinarlı, İ. (2019). Relations between sports consumption motives of football spectators, risk perceptions and future intends. Master Thesis Ege University Institute of Health Sciences, Izmir.

Cini, N. G. (2018). The relationship beetwen the motivation for sport online consumption and points of attachment of the professional football team fans. Master Thesis Ege University Institute of Health Sciences, İzmir.

Cohen, R. (2016). Sport psychology: The basics optimising human performance (pp. 14-16). London-New York: Bloomsbury Sport.

Cokportal, C. (2015). An investigation on football fans' motivation for sport consumption: Example of besiktas gymnastic club-kardemir karabukspor fans. Master Thesis Abant Izzet Baysal University Institute of Social Sciences, Bolu.

Elmas, M., \& Balcı, V. (2019). The effect of childrens on parents sporting goods consumption decisions. Journal of Global Sport and Education Research, 2(1), 1-9.

Elmas, M. (2018). Researching of university students sport consumption. Master Thesis Ankara University Institute of Health Sciences, Ankara.

Elmas, M., \& Balc1, V. (2019). Researching of university students sport consumption. Turkish Journal of Sport and Exercise, 21(1), 175-181.

Erdoğ, M. O. (2012). Sports marketing activities: Example of Beşiktaş Football Club. Unpublished MA Thesis. Bahcesehir University Institute of Social Sciences, Istanbul.

Erhan, S., Bedir, D., Güler, M., \& Ağduman, F. (2015). An assessment of athletic psychological skills inventory: Example of Turkısh development and validity. Atatürk University Journal of Physical Education and Sport Sciences, 17(1), 59-71.

Erkan, M., \& Uslu, N. Ç. (2019). Determining the scope of sports participation sports industry profile (Turkey Example). GSI Journals Serie A: Advancements in Tourism Recreation and Sports Sciences, 1(2), 40-53.

Fraenkel, J. R., \& Wallen, N. E. (2006). How to design and evaluate research in education. Boston: McGraw-Hill.

Gençer, R. T., Kiremitçi, O., Aycan, A., Demiray, E., \& Unutmaz, V. (2012). The relationship between the motives and points of attachment of the professional football team spectators. Ege Academic Review, 12(SI), 41-53.

Giray, C., \& Girişken, Y. (2015). The effect of fan motivation factors on behavioral loyalty: The case of fenerbahçe sports club. Journal of Economic and Social Research, 11(2), 119-137.

Ha, J. P., Kang, S., J., \& Kim, Y. (2017). Sport fans in a "smart sport” (SS) age: Drivers of smartphone use for sport consumption. International Journal of Sports Marketing and Sponsorship, 18(3), 281-297.

Hanks, K. (1999). The art of motivation for people. Trans: Can İkizler (pp. 1-7). Istanbul: Alpha Publishing.

Karatoprak, T. (2019). The relationship between the levels of identification and consumption of sports organizations of sports fans engaged in sports: The city of ordu. Master Thesis. Ordu University Institute of Health Sciences. Ord.

Karayol, M., \& Eroğlu, S. Y. (2020). Examining the occupational ethics and professional motivation status of physical education and sports teachers: The example of Muş Province. Anemon Muş Alparslan University Journal of Social Sciences, 8(2), 655-664.

Keser, A. (2006). Motivation in working life (pp. 2-5). Istanbul: Alfa Akademi.

Kim, M. J., \& Mao, L. L. (2019). Sport consumers motivation for live attendance and mediated sports consumption: A qualitative analysis. Sport in Society, 1-19.

Kurtipek, S., Güngör, N. B., Esentürk, O. K., Ilhan, E. L., \& Yenel, F. (2020). Department of sports management with students' perspectıve: A swot analysis. SPORMETRE the Journal of Physical Education and Sports Sciences, 18(1), 187-194.

Middleton, J. A., \& Toluk, Z. (1999). First steps in the development of an adaptive theory of motivation. Educational Psychologist, 34(2), 99112.Available at: https://doi.org/10.1207/s15326985ep3402_3.

Murathan, T., \& Murathan, F. (2019). Blockchain applications in sports sector. Gaziantep University Journal of Sport Science, 4(1), 64-74.

Ozgün, A., Yaşartürk, F., Ayhan, B., \& Bozkuş, T. (2017). Examination of handball players' levels of sports-specific achievement motivation and happiness. International Journal of Cultural and Social Studies, 3(SI), 83-94.

Simşek, K. Y. (2012). Sport consumption factors of Turkish extreme sportsmen. Ege Academic View Magazine, 12(SI), 71-84.

Simşek, K. Y. (2011). The impact of the extreme sports consumption motives on the percived value, percived satısfaction and behavioral intentions of the extreme sport participants in Turkey. PhD Thesis Anadolu University Institute of Health Sciences, Eskișehir.

Tevruz, S. (2002). Personal development in organizations. Self-Motivation, Ed .: A. Esra Aslan (Vol. 96). Ankara: Nobel Publishing.

Tok, S. (2004). Motivational factors affecting sports consumption behaviours and the adaptation of sport consumption scale into Turkish (Izmir Province Case). Master Thesis Ege University Institute of Health Sciences, Izmir.

Trail, G. T., \& James, J. D. (2001). The motivation scale for sport consumption: Assessment of the scale's psychometric properties. Journal of Sport Behavior, 24(1), 108-127.

Vallerand, R. J., Pelletier, L. G., Blais, M. R., Briere, N. M., Senecal, C., \& Vallieres, E. F. (1992). The academic motivation scale: A measure of intrinsic, extrinsic, and amotivation in education. Educational and Psychological Measurement, 52(4), 1003-1017.Available at: https://doi.org/10.1177/0013164492052004025.

Xianliang, L., \& Hongying, Y. (2012). The quantitative analysis on the individual characteristics of urban residents and their sport consumption motivation. Physics Procedia, 33, 2055-2063.Available at: https://doi.org/10.1016/j.phpro.2012.05.323.

Yüce, A. (2019). Sustainable sports consumer behaviour. PhD Thesis Anadolu University Institute of Social Sciences, Eskişehir. 